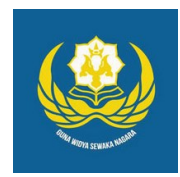

Jurnal Analogi Hukum

Journal Homepage: https://ejournal.warmadewa.ac.id/index.php/analogihukum

\title{
Asas Itikad Baik dalam Perjanjian Jual Beli Barang Melalui Media Elektronik (E-Commerce)
}

\author{
I Wayan Agus Grahadi Putra*, I Nyoman Putu Budiartha dan Ni Made Puspasutari Ujianti \\ Universitas Warmadewa, Denpasar-Bali, Indonesia \\ *grahhadi.p.agus@gmail.com
}

\begin{abstract}
How To Cite:
Putra, I, W, A, G., Budiartha, I, N, P., Ujianti, N, M, P. (2020). Asas Itikad Baik dalam Perjanjian Jual Beli Barang Melalui Media Elektronik (ECommerce). Jurnal Analogi Hukum. 2 (3). 320--325. Doi: https://doi.org/10.22225/ah.2.3.2507.320-325
\end{abstract}

\begin{abstract}
Technological developments affect all aspects of life that make life easier or more instant. One aspect of this technology is affected by the purchase agreement. This agreement was initially carried out by businessmen meeting with a buyer in a place (the market), today this agreement can be done simply by using mobile phones that have internet we are able to make buying and selling the so-called E-Commerce. As for the formulation of the problem 1. How is the validity of the Sale and Purchase Agreement using Electronic Media (E-Commerce) for the parties who make it? How is the Good Faith Principle in the Sale and Purchase Agreement of Goods using Electronic Media (E-Commerce)? This research uses normative research methods. The results of this study are Effect of E-Commerce has changed the way a person to transact in the electronic media have a positive impact for both side. When there is a positive impact then of course there are negative impacts, the negative impact entrepreneurs often commit fraud in transactions because they do not meet in person only meet in cyberspace alone. So in the world of E-Commerce importance of implementing in good faith greatly influence the nets of a business because when it has been using the good faith of both parties will not commit fraud with each other.
\end{abstract}

Kata Kunci: purchase agreement; e-commerce; good faith

Abstak-Perkembangan teknologi sangat mempengaruhi semua aspek kehidupan sekarang yang membuat kehidupan semakin instan atau lebih mudah. Salah satu aspek yang terpengaruh dari teknologi ini adalah perjanjian jual beli. Perjanjian ini awalnya dilakukan dengan pertemuan pelaku usaha dengan pembeli pada sebuah tempat (pasar), jaman sekarang perjanjian ini bisa dilakukan hanya dengan menggunakan handphone yang memiliki internet kita sudah dapat melakukan transaksi jual beli yang dinamakan E-Commerce. Adapun rumusan masalah 1. Bagaimana Keabsahan Perjanjian Jual Beli Barang menggunakan Media Elektronik (ECommerce) bagi para pihak yang membuatnya? Bagaimana Asas Itikad Baik dalam Perjanjian Jual Beli Barang menggunakan Media Elektronik (E-Commerce)? Penelitian ini menggunakan metode penelitian normative. Hasil dari penelitian ini adalah Pengaruh E-Commerce ini telah merubah cara seseorang untuk bertransaksi di media elektonik yang membawa dampak positif bagi kedua pihaknya. Bila terdapat dampak positif maka tentunya terdapat dampak negatif yang ditimbulkan, dampak negatifnya para pelaku usaha sering kali melakukan penipuan dalam transaksi karena mereka tidak bertemu secara langsung hanya bertemu di dunia maya saja. Maka dalam dunia E-Commerce pentingnya penerapan itikad baik sangat mempengarui jalannya suatu usaha karena bila telah mempergunakan itikad baik kedua belah pihak akan tidak melakukan penipuan satu sama lainya.

Kata Kunci: Perjanjian jual beli; e-commerce; Itikad baik

\section{Pendahuluan}

Perubahan teknologi mendorong adanya hal baru dibidang komputer, komunikasi berserta perkembangan teknologi internet. Perkembangan internet merubah semua aspek yang ada menjadi semakin efesien. Dengan adanya perkembangan internet dalam suatu perjanjian jual beli juga berubah tidak seperti dulu lagi. Pengaruh internet ini membuat orang - orang yang melakukan jual beli tidak bertemu langsung namun bertemu melalui internet yang biasa disebut dengan e-commerce. E-commerce adalah suatuperjanjian jual beli yang mempergunakan internet sebagai media 
pengguhung kedua belah pihak ini (https:// www.nesabamedia.com/pengertian-fungsi-danmanfaat-internet-lengkap/). Penggunaan internet untuk transaksi bisnis sudah dianggap sebagai suatu hal yang penting, hal ini ditandai dengan meningkatnya jumlah pengusaha yang menggunakan e-commerce dalam perusahaannya (Maulana, Susilo, \& Riyadi, 2015).

Jual beli melalui media eletronik ini telah digunakan oleh semua kalangan untuk mengefesiankan waktu serta bisa mendapatkan harga yang lebih murah atau terjangkau. Karena pelaku usaha didalam memasarkan barang dagangannya tidak memerlukan toko fisik hanya melalui alamat web ataupun dengan sosial media yang lainnya, sehingga hal tersebut akan menghemat pengeluaran atau modal dari pelaku usaha online tersebut. Hal tersebut telah membuat adanya aturan mengenai e-commerce tersebut yang tertuang dalam Undang Undang nomer 19 tahun 2016 tentang Teknologi Informasi dan Transaksi Elektronik.

E-commerce pada dasarnya hampir sama seperti perjanjian jual beli pada umumnya namun yang membedakan perjanjian melalui media elektronik ini tidak dilakukan dengan bertemu langsung hanya bertemu melalui media internet. Pengaruh ini memberi dampak yang baik atau positif karana dengan adanya perkembangan teknologi ini masyarakat menjadi lebih efisien dalam melakukan jual beli beserta dapat menjadi peluang usaha yaitu menjadi pengantar barang dari penjual ke pembeli.

Berbicara mengenai dampak positif tentu ada dampak negative yang ditimbulkan. Dampak negatif dari adanya e-commerceini membuat orang - orang menjadi malas untuk bersosialisasi dengan sesama, malas keluar rumah beserta pemanfaatan penipuan dalam ecommerce ini. Penipuan sering kali terjadi dalam transaksi ini karena pelaku memanfaatkan tidak bertemu nya kedua belah pihak dalam perjanjian maka dengan begitu adanya suatu itikad baik dalam transaksi ecommerce ini sangat penting. Menurut Pasal 1338 ayat (3) KUHPdt, setiap orang diperbolehkan membuat perjanjian dengan siapapun dan tentang apapun sepanjang memenuhi syarat yang ditentukan dalam peraturan perundang-undangan, dan kepatutan dalam masyarakat. Penggunan asas kebebasan berkontrak ini akan dapat merugikan pihak konsumen, untuk melindungi konsumen, maka harus dilakukan dilakukan pembatasanpembatasan. Salah satu pembatasannya adalah asas itikad baik (Winarni, 2015). Hal tersebut harus lebih memperhatikan bagaimana penerapan itikad baik dalam e-commerce yang tidak dilakukan dengan bertemu langsung maka bila telah ada itikad baik maka perjanjian itu akan lancar dan tidak ada penipuan atauhal negative yang dapat ditimbulkan (Satriyo, 2008).

Berdasarkan apa yang telah penulis jelaskan di dalam latar belakang di atas, maka penulis dapat mengkaji 2 (dua) permasalahan di dalam skripsi ini yaitu :

Bagaimana Keabsahan Perjanjian Jual Beli Barang menggunakan Media Elektronik (ECommerce) bagi para pihak yang membuatnya?

Bagaimana Asas Itikad Baik dalam Perjanjian Jual Beli Barang menggunakan Media Elektronik (E-Commerce)?

Adapun tujuan dari penelitian ini yang dapatbagi menjadi 2 (dua) yaitu: Tujuan umum dan tujuan Khusus. Tujuan umum dari penelitian ini adalah:

Agar dapat mengembangkan Ilmu Pengetahuan Hukum yang telah di dapat;

Sebagai syarat formal bagi mahasiswa untuk memperoleh gelar Sarjana Hukum pada Fakultas Hukum Universitas Warmadewa; Tinggi;

Melaksanakan Tri Dharma Perguruan

Mampu memberikan penjelasan bagaimana keabsahan dalam perjanjian jual beli melalui media elektronik beserta bagimana penerapan itikad baik dalam (E-Commerce) agar terciptanya keuntungan bersama.

Tujuan Khusus dari penelitian ini adalah:

Untuk mengetahui bagaimana kebsahan dari perjanjian jual beli melalui media elektronik yang mana perjanjian ini dilakukan tidak melalui bertemu langsung;

Mengetahui bagaiamana penerapan itikad baik yang menjadi dasar dalam transaksi ECommercebeserta penanganan bila terjadi sengketa antara kedua belah pihak.

\section{Metode}

Penelitian ini menggunakan metode penelitian Normatif, dimana penulis mengumpulkan bahan yang dapatkan melalui pendekatan Perundang-undangan, Pendekatan konseptual, melakukan perbandingan hukum, serta didasari dan di dukung bahan hukum primer, sekunder dan tersier. Pada bahan hukum primer meliputi KUHperdata, KUHPidana, 
Undang - Undang Republik Indonesia Nomor 8 Tahun 1999 Tentang Perlindungan Konsumen, Undang-Undang Republik Indonesia Nomor 11 Tahun 2008 Tentang Informasi dan Transaksi Elektronikbeserta Undang-Undang Republik Indonesia Nomor 19 Tahun 2016 Tentang Perubahan Atas Undang-Undang Nomor 11 Tahun 2008 Tentang Informasi Dan Transaksi ElektronikTentang Informasi dan Transaksi Elektronik. Pada bahan hukum sekunder meliputi bahan dari buku atau literatur, jurnal hukum, situs web, artikel-artikel, pendapat sarjana terkait dengan permasalahan ini. Sedangkan dalam bahan hukum tersier meliputi bahan-bahan hukum penunjang yang memberikan petunjuk dan penjelasan terhadap bahan-bahan hukum primer dan bahan hukum sekunder, seperti kamus hukum, surat kabar, majalah dan internet juga dapat digunakan bahan bagi penelitan ini sepanjang memuat informasi yang berhubungan.

Pengumpulan Bahan Hukum yang penulis lakukan adalah dengan cara studi pustaka dan studi dokumen. Yaitu dengan cara membaca dan mencatat informasi serta penjelasan yang diperoleh baik dari Undang - Undang, Peraturan Pemerintah yang di dapatkan dari sumber hukum tersebut yang dapat dikaji lebih lanjut yang berhubungan dengan permasalahan ini.

Dalam penulisan ini Analisis Bahan Hukum yaitu setelah semua bahan hukum terkumpul selanjutnya di analisis mengenai bahan-bahan hukum seperti perundangundangan serta buku-buku yang di dapat dan dipinjam diperpustakaan dan menguraikan permasalahan yang dibahas untuk mendapatkan jawaban dari permasalahan tersebut.

\section{Hasil Penelitian Dan Pembahasan}

\section{Keabsahan Perjanjian Jual Beli Barang Menggunakan Media Elektronik (E- Commerce) Bagi Para Pihak Yang Membuatnya}

Pengaturan mengenai keabsahan ECommerce sebenarnya sudah ada dalam Undang - Undang Nomor 11 Tahun 2008 Tentang Informasi dan Transaksi Elektronik pada pasal Pasal 1 ayat (17) yaitu kontrak elektronik adalah perjanjian para pihak yang dibuat melalui sistem elektronik. Para pihak dalam transaksi ini juga hampir sama dengan transaksi jual beli pada umunya namun ada tambahan karena merupakan salah satu sarana penunjang untuk menjalakan jual beli ini yaitu provider yang mana sebagai penyediajasa layanan akses internet yang memiliki kewajiban untuk menyediakan layanan akses internet 24 jam kepada calon pembeli untuk dapat melakukan transaksi jual beli secara elektronik melalui media internet dengan pelaku usaha yang menawarkan produk lewat internet tersebut, dalam hal ini terdapat kerjasama antara penjual atau pelaku usaha dengan provider dalam menjalankan usaha melalui internet ini (Prasetyo, 2005).

Namun pada kenyataan dalam masyarakat masih banyak yang meragukan tentang keabsahan perjanjian jual beli melalui media elektronik ini. Banyak masyarakat yang masih meragukan keabsahannya karena banyaknya terjadi penyimpangan seperti barang yang tidak sesuai dengan gambar, wanprestasi terhadap barang tersebut, bahkan penipuan mengingat dalam transaksi ini tidak dilakukan dengan bertemu secara langsung yang mana dari pihak pembeli hanya dapat melihat gambar yang telah di post dalam website atau blogspot tempat dimana hanya bertemunya pelaku usaha dengan pembeli, maka dengan mudahnya pelaku usaha melakukan penipuan dengan itikad tidak baik kepada pembeli dengan hanya mengambil uang yang dibayarkan tanpa mengirim barang kepada pembeli. Perbuatan-perbuatan tersebutlah yang membuat banyaknya masyarakat tidak percaya akan E-Commerceini.

Padahal bila masyarakat menggunakan ecommerce akan menjadi lebih mudah dan efesien yang tidak perlu lagi pergi ke mall untuk mencari barang yang diinginkan yang dapat dilakukan dirumah saja hal tersebut dapat menghemat waktu. Selain itu bila menggunakan e-commerce juga dapat melakukan pencarian dengan harga yang sesuai dengan budget kita melalui mesin pencari atau search engine yang telah ada dalam website atau blogspot tersebut, selain hal tersebut barang yang kita pesan juga dapat langsung diantar ke rumah kita berdasarkan alamat yang kita cantumkan dalam pembuatan form order tersebut. Kelebihan tersebut juga dapat rasakan oleh pelaku usaha yang mana bila menggunakan ecommercepelaku usaha tidak perlu membuat ruko atau toko untuk menjual barangnya tersebut hanya dengan mempromosikannya di sosial media atau website tempat pelaku usaha berjualan (Sanusi, 2001). Hal tersebut menjadi kelebihan yang dapat kita nikmati bila menggunkan e-commerce. Namun semakin banyaknya pelaku usaha yang menggunakan $e$ commerce tidak terlepas dari prilaku yang dilakukannya maka timbulah perbuatan untuk merugikan pembeli dengan melakukan penipuan atau wanprestasi terhadap barang 
tersebut.

\section{Asas Itikad Baik dalam Perjanjian Jual Beli Barang menggunakan Media Elektronik (E- Commerce)}

Untuk meningkatkan kepercayaan dalam masyarakat maka pelaku usaha yang ingin melakukan kegiatan jual beli melalui media elektronik (E-Commerce) harus didasari dengan itikad baik yang mana akan menjadi dasar atas perbuatan yang dilakukan, hal tersebut akan berpengaruh kepada kepercayaan pelanggan sehingga tidak berfikiran mengenai transaksi ini. Penerapan itikad baik tersebut bisa diterapkan dengan memperlihatkan beberapa hal yaitu:

\section{Memberikan informasi yang pasti}

Sudah menjadi kewajiban pelaku usaha untuk memberikan semua informasi mengenai barang yang diperjualbelikan oleh pelaku usaha kepada pembeli yang berkaitan dengan jual beli ini. Memberikan informasi ini harus jelas dan tidak dibuat buat. Hal tersebut akan menambah minat dari pembeli karena dari pelaku usaha dapat memberi informasi yang sudah jelas dan dapat menjadi pertimbangan dari pembeli untuk mencari hal yang pembeli inginkan. Contohnya pelaku usaha dapat memperlihatkan testimony (hasil penjualan dari pembeli lain yang dapat memberi saksi atas barang yang dijual oleh pelaku usaha tersebut) dengan begitu pembeli akan semakin percaya pada pelaku usaha, berserta dalam penjualan bisa ditambahkan dengan ukuran suatu barang yang dijual misalnya baju yang berukuran $\mathrm{L}(57 \mathrm{~cm} \times 60 \mathrm{~cm})$ M $(50 \mathrm{~cm} \times 55 \mathrm{~cm})$ dan sebagainya.

\section{Identitas asli Pelaku Usaha}

Memberikan identitas asli dari pelaku usaha dalam menjalakan kegiatan jual beli menggunakan media elektronik (E-Commerce) perlu dilakukan oleh pelaku usaha yang mana dalam transaksi ini tidak dilakukan dengan bertemu secara langsung namun bertemu dengan menggunakan media elektronik. Identitas ini yang akan digunakan sebagai acuan jika terjadi sesuatu mengenai barang yang di perjualbelikan. Perlunya memberi identitas para pelaku usaha ini sebagai tanggung jawab dari pelaku usaha mengenai barang yang di pesan oleh pembeli bila terjadi cacat yang tersembunyi dapat dimintakan ganti rugi yang mana pelaku usaha harus bersedia melakukannya dengan itikad baik. Penempatan identitas tersebut biasnya ditancumkan dalam bawah website atau blogsopt agar lebih mudah mencarinya.

Informasi dimana pabrik atau proses pembuatan pelaku usaha

Informasi dimana pabrik pelaku usaha ini berguna bila para pembeli yang mengalami kerugian dapat langsung menuju tempat pembuatan barang tersebut dan memintai penjelasan akan barang yang diterimanya tidak sesuai dengan apa yang ada di foto dalam website atau blogspot tersebut. Dapat juga dimintai ganti rugi atas kelalaian pelaku usaha dalam hal ini (Basarah, 2011).

Bila masih ada pelaku usaha yang tidak melakukan hal tersebut dan tetap melakukan penipuan artinya memang dari awal tujuan dari pelaku usaha bukan untuk berjual. Beberapa faktor yang dapat menjadi alasan terjadinya penipuan dalam E-Commerce:

belum meratanya sertifikasi penerapan informasi terhadap setiap pelaku dalam jual beli secara online, yang menyebabkan mudahnya bagi pelaku usaha untuk berjualan dengan maksud hanya menguntungkan dirinya sendiri dan ingin merugikan pembeli.

Akses internet yang tidak terbatas, dengan akses internet yabg tak terbatas ini disamping membawa dampak positif juga dapat menimbulkan dampak negatif seperti dapat mengakibatkan terjadinya penipuan yang dilakukan oleh pelaku usaha yang tempatnya jauh dengan pembeli.

Para pelaku merupakan orang yang pada umumnya cerdas, mempunyai rasa ingin tahu yang besar dan fanatik akan teknologi komputer. Dampak tersebut bila tidak dibimbing dengan baik maka akan menjadi pelaku usaha yang melakukan penipuan terhadap pembeli lainya karena kepintaranya di bidang teknologi.

Peluang keberhasilan yang cukup tinggi, para pelaku usaha yang melalukan tindak penipuan dalam transaksi ini biasanya memikirkan peluang yang akan dihasilkan memiliiki keuntungan cukup tinggi dan keamaan yang tinggi pula yang mana pelaku tindak penipuan ini hanya menjual gambar tanpa barang aslinya (Apriansyah, n.d.).

Berdasarkan hal tersebut penerapan itikad baik sangat penting dalam pemenuhan hak dan kewajiban yang dilakukan oleh pelaku usaha dan pembeli dalam transaksi ini karena transaksi ini tidak dilakukan dengan bertemu langsung.Bila para pelaku usaha melakukan penipun bila telah adanya hukum yang 
mengatur maka dari pihak yang dirugikan dapat nuntut dengan dua cara yaitu :

Non litigasi atau cara damai

Penyelesaian sengketa secara damai lebih dikenal dengan penyelesaian secara musyawarah mufakat. Dalam penyelesaian sengketa secara damai tidak ada para pihak yang mengambil keputusan bagi penyelesaian sengketa. Keterlibatan pihak ketiga dalam penyelesaian sengketa secara damai adalah dalam rangka mengusahakan agar para pihak yang bersengketa dapat sepakat untuk menyelesaian sengketa mereka. Suatu sengketa yang terjadi dalam E-commerce biasanya dilakukan menggunakan cara mediasi dimana Mediasi menjadi salah satu bentuk penyelesaian yang sering dipilih oleh para pihak yang bersengketa dalam sengketa e-commerce. Melalui mediasi pihak ketiga yang netral akan mempertemukan kedua pihak lalu duduk bersama-sama dengan para pihak yang bersengketa dan secara aktif akan membantu para pihak dalam upaya menemukan kesepakatan yang adil dan memuaskan bagi keduanya. Dalam proses mediasi, seorang mediator hanya berperan sebagai fasilitator saja. Mediator tidak mempunyai kewenangan untuk membuat suatu keputusan yang mengikat para pihak. Sedangkan cara lainya yaitu menggunakan mekanisme konsuliasi dimana pihak ketiga yang akan membantu, telah membawa usulan penyelesaian, sehingga berperan lebih aktif dalam mengarahkan para pihak untuk sampai pada kesimpulan penyelesaian sengketa yang dapat disepakati para pihak, Dalam melakukan proses konsiliasi, seorang konsiliator harus mampu mengetahui situasi dan kondisi kasus tersebut, mengetahui apa yang menjadi keinginan para pihak yang bersengketa serta mengetahui kebutuhan para pihak agar sengketa dapat diselesaikan secara cepat (Nugroho, 2015).

\section{Litigasi atau pengadilan}

Bila dalam sengketa E-commerce tidak dapat diselesaikan dengan menggunkan mediasi atau cara damai pihak yang dirugikan bisa mengajukan gugatan ke pengadilan dengan mempertimbangkan kerugian yang dideritanya berserta bukti bukti yang dapat memperkuat alasanya tersebut berdasarkan pasal 18 dalam Undang-Undang No 11 Tahun 2008 mengenai Tenologi dan Informasi adalah melalui lembaga pengadilan. Kejahatan e-commerce yang telah masuk pada ranah pidana maka ketentuan dalam peraturan perundang-undangan telah mengaturnya, yakni UU Nomor 11 Tahun 2008 tentang Informasi dan Transaksi Elektronik beserta dalam KUHPerdata mengenai penipuan yang mengakibatkan pihak lain mengalami kerugian cukup besar (Nugroho, 2015).

Bila semua aspek telah terpenuhi dengan menjalankan itikad baik yang mana dari pelaku usaha atau pembeli maka transaksi dalam ecommerce akan berjalan lancar tanpa adanya sengketa.

\section{Simpulan}

Berdasarkan hasil pembahasan permasalahan di atas maka dapat menarik simpulan yaitu:

Keabsahan jual beli melalui media elektronikE-Commerce berdasarkan atas kata sepakat antara kedua belah pihak yang ada didalam perjanjian jual beli melalui media elektronik ini sama hal nya pada perjanjian pada umunya yang membedakan hanya perjanjian ini tidak dilakukan dengan bertemu langsung namun bertemu didunia maya. Perjanjian E-Commerce harus selalu dilandasi atas itikad baik bagi kedua belah pihak dan harus memenuhi hak dan kewajiban yang ditanggung oleh kedua belah pihak.

Penerapan itikad baik yang dapat dilakukan pelaku usaha dalam menjalakankan kegiatan jual beli online ini perlaku usaha harus memberikan informasi yang sebenar benar nya mengenai barang yang akan dijualakan dan harus memerikan identitas pelaku usaha sendiri sebagai tanggung jawab dari pelaku usaha tersebut. Sedangkan bila terjadi sengketa proses penyelesaian sengketa dalam transaksi jual beli melalui media elektronik dapat diselesaikan memalui 2 jalur yang pertama melaui jaur litigasi atau jalur pengadilan yang dapat menuntut pelaku usaha berdasarkan pasal 378 KUHP karena melakukan penipuan kepada pembeli yang tidak beritikad baik, cara penyelesaian yang kedua dapat dilakukan dengan penyelesaian damai yang mana dalam penyelesai ini harus beritikad baik yang mana dapat dilakukan dengan mediasi, negosisasi bila memang benar pihak pelaku melakukan kesalahan dalam transaksi jual beli melaui media elektronik ini.

\section{Daftar Pustaka}

Apriansyah, A. (n.d.). Faktor - Faktor Penyebab Cybercrime. Retrieved from kelompok-5.wixsite.com/avnna/singlepost/2015/04/07/Faktor-PenyebabPenipuan-

Basarah, M. (2011). Prosedur Alternatif Penyelesaian Sengketa; Arbitrase 
Tradisional dan Modern (Online).

Genta Publishing.

Maulana, S. M., Susilo, H., \& Riyadi. (2015). IMPLEMENTASI E-COMMERCE SEBAGAI MEDIA PENJUALAN ONLINE (STUDI KASUS PADA TOKO PASTBRIK KOTA MALANG). Jurnal Administrasi Bisnis (JAB), 29 (1). Retrieved from https:// media.neliti.com/media/ publications/86512-ID-none.pdf

Nugroho, S. A. (2015). Penyelesaian Sengketa Arbitrase dan Penerapan Hukumnya Edisi Pertama. Jakarta: Prenadamedia Group.

Prasetyo, A. H. B. D. T. (2005). Bisnis ECommerce: Studi Sistem Keamanan Dan Hukum Di Indonesia. Yogyakarta: Pustaka Pelajar.

Sanusi, A. (2001). Internet Hukum Dan Solusinya. Bandung: Mizan Pustaka.

Satriyo, W. F. (2008). Membuat Surat - Surat Kontrak. Jakarta Selatan: Visimedia.

Winarni, L. N. (2015). Asas Itikad Baik Sebagai Upaya Perlindungan Konsumen Dalam Perjanjian Pembiayaan. DiH: Jurnal Ilmu Hukum, 16(2). Retrieved from http:// jurnal.untag-sby.ac.id/index.php/dih/ index 